\title{
NOTES ON LEPROSY SETTLEMENTS TANGANYIKA TERRITORY
}

\author{
A. G. MАСKAY.
}

The Role of Settlements.

(I) To segregate infective lepers with a view to reducing the incidence of leprosy in the area served by the settlement.

(2) To provide a centre for training in leprosy work.

(3) To set a standard for treatment which would be generally adopted throughout the Province in which the settlement is situated.

The opening of a leprosy settlement makes the surrounding community leprosy-conscious, and is a valuable step in propaganda towards diminution of the spread of infection.

As regards training this does not only mean the tuition of 
selected Africans in the treatment of leprosy. It entails special courses of instruction for any, e.g. Missionaries, who wish to take advantage of the special tuition. Medically qualified Africans of the Hospital Assistant class can be trained in the administration of settlements as well as in the general care of lepers.

Advantages of Provincial SetTllaments over Main TI:RRITORIAL SETTLLEMENTS.

(I) The difficulty of transporting lepers by rail is avoided.

(2) Patients will more readily go to a settlement in or near their own tribal area.

(3) Less admixture of diffierent tribes in a settlement facilitates administration.

(4) There is less climatic change for the patients and less environmental change in agricultural and social conditions.

(5) They form local centres where Africans, chosen from nearby tribes and who will later act as orderlies for the treatment of leprosy, or who will take part on leprosy surveys, can be recruited, trained and sent out to work in the tribal areas to which they belong.

Siting of Settumments.

(I) Sufficient cultivatable land and good water supplies are essential if the costs of running a settlement are to be kept down. If plenty of fertile land is not available, it means that the settlement will be largely industrial rather than agricultural, and that foodstuffs will have to be imported. Plentiful water supplies are necessary, not only because of cultivation, but because the provision of bathing facilities is an important adjuvant in treatment.

(2) Climate has to be considered as it has an influence on leprosy. Lepers respond better to specific therapy when they are not exposed to considerable variations in temperature and high rainfall.

(3) Communications should be good all the year round to allow of supervision from the nearest Government station.

(4) Qualified medical aid should be available within a reasonable distance when the settlement does not have its own doctor and hospital. (Every settlement should have its own dispensary with a sick bay and its African medical staff, even though this is only of the hospital orderly standard.)

Population.

A population of 500 constitutes a medium-sized settlement. 
Populations of 1,000 and over require their own hospital and doctor.

Area required depends on the fertility of the soil when the settlement is to be self-supporting agriculturally. At Makete, where lepers are segregated with their families, four or five acres of land suffice for one family. In less fertile areas, e.g. in the Western Province, eight acres per family may be required.

The Planning of a Settlement has to be undertaken similarly to making a Sleeping Sickness Concentration. A preliminary survey of the land is essential, and food has to be imported in advance to be issued to the patients until the first harvest within the settlement has been gathered. A certain number of huts have to be built in advance; thereafter, newcomers build their own huts.

The function the settlement has to perform in relation to the community has to be pre-determined. Generally speaking, if the incidence of leprosy in the Province is relatively low, more latitude can be allowed as regards the type of case admitted. Where the incidence or rate of open cases is high, only the most infectious types should be admitted, and every endeavour should be made to step up the discharge rate of disease-arrested cases. "Burnt-out" cases should be excluded-they are no longer suffering from leprosy. Their welfare comes within the province of the infirm and paupers in general. This is a matter for the Native Administration functioning as a Poor Law Authority. The incidence of leprosy varies in different parts of the Territory. From the preventative medicine standpoint, what is more important than the total number of cases in a given area is the percentage of open lepromatous cases amongst them, especially a high percentage of lepromatous cases amongst children compared to adults. The neural type may be regarded as for all practical purposes non-infective. An average type-distribution in Central Africa might be taken to be 5-10\% lepromatous, I5\% mixed and $75-80 \%$ neural.

As admissions are voluntary, it is most important that the conditions within the settlement are made as attractive as possible, and that the patient on entering should be made to feel at ease from the very start. Social life within the settlement should preserve the conditions of village life outside as far as circumstances permit, except that the standard of sanitation will be maintained at a higher level.

The idea is to segregate highly infective cases only. The great difficulty in dealing with primitive peoples, however, is to be able to isolate the patient away from his family. The African 
(who dees not believe in infection in the Western sense) is unwilling to be separated from his or her family unless for a very short period. There is the further problem of families left uncared for through isolation of their head. It is probably best to make a gradual approach to the ideal of segregating infective cases. Until the outside community has become leprosy-conscious segregation with complete families (if so desired) should be allowed. Later the further step can be taken of separating the infective members of the family within the Settlement, when the reason for this has been appreciated by those concerned. Conjugal infections are so infrequent that separation of husband and wife is rarely necessary, but uninfected children have to be provided for in a special area within the settlement. Children born in the settlement are a special problem. Generally they escape infection If separated from infective mothers within six months of birth, but after that period the incidence of infection amongst them (as shown say two to four years later) is liable to be high. Unless some form of guardianship amongst relatives outside can be arranged, the special provision for uninfected children within the settlement has to be borne in mind when the total area required for the settlement is calculated. The British Empire Leprosy Association finances a child adoption scheme which pays for the care of infected children isolated in special areas within settlements.

At Makete Leprosy Settlement the incidence of the disease amongst healthy children brought with infected parents has been surprisingly low. The reason for this may be certain Wanyakyusa customs. One is that the tribal hut is relatively large and is oblong in shape, and advantage has been taken of this to insist (on large huts within the settlement; familial contact is thereby reduced. Children eat with the mother (although older boys eat with the father). If the father is infective, there is therefore less contact at the youngest and most susceptible ages. Youths leave home and occupy a separate part of the village. Water supplies are plentiful and the Wanyakyusa are cleanly in their habits under such conditions.

Also, during the last few years, more and more separation of the infective and non-infected within the family has been carried out.

The Admenistration of a Settlement should be a joint responsibility. The more people interested in it, the better for the seltlement. Makete is an example of this. The District Commissioner, Rungwe, lives at Tukuyu, I2 miles away. He controls the finances of the Colony, and approves the admission 
of patients recommended by the. Medical Officer, Tukuyu. The latter visits the settlement at frequent and regular intervals and is responsible for its medical activities. A Toc H Leprosy Worker is in immediate control, and lives within one mile of the nearest patients huts. Discipline is maintained by the local Native Authority. a Chief visiting at regular intervals to hear disputes. Finally, each of the three villages within the settlement area has an Elder in charge of it. This combined form of administration works very satisfactorily.

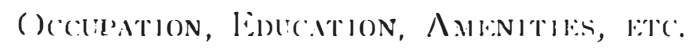

While agriculture is necessarily the main occupation, the tearhing of trades and of handicrafts should be encouraged. Not only are the results of such occupations revenue-producing, but they are also necessary for the settlements own needs. Whatever the work of the various members, occupation should be regarded primarily as occupational therapy and for the production of the settlement's requirements. It should not be made subservient to producing as much as possible for sale outside in order to get revenue. Leprosy settlements have never yet become selfsupporting and must necessarily be a liability on public funds. The cost per head per annum varies from the surprisingly low figures of Shgs. IO/- at Makete to $£ 5$ in some West African Agricultural Leprosy Settlements. The Oji River Settlement costs just over $£^{2}$ per head per annum, and there expense is kept down by the scheme whereby all patients able to work must contribute a portion of their time in unpaid work in the Settlement.

The education of children must not be neglected, and two schools may be required, one for infected children and the other for healthy children.

Facilities must be provided for religious worship.

A market should be provided for the interchange of produce within the settlement, and a shop for the sale of small luxuries is always greatly appreciated.

A recreation ground will be required for the young, and a large hut as a meeting place for the elder members of the community.

In addition to the clinic where patients receive their injections there must be a dispensary for the treatment of general diseases, and here again provision must be made for treating in separate rooms infective lepers and the other members of the community who do not suffer from leprosy. A microscopist and laboratory facilities are very important.

A Court House for the hearing of all disputes should be 
provided, and a system for the election of Elders qualified to decide disputes.

Finally, as bathing is both a prophylactic and a therapeutic agent (the latter through its tonic effect on the system) bathrooms fitted with showers should be available.

DISCHARGE OF DISEMST:-IRRISTTED CASES.

A local Examining Board should visit yearly or twice yearly to decide which patients can with safety be allowed to return to their native villages. Before discharge, a patient should be bacteriologically negative for at least one year, and he should be instructed to report at the Settlement or at a Dispensary once every six months to see if he remains negative. If the patients are contented in the Settlement, and they generally are if the Settlement is well run, there is rarely any difficulty in getting a relapsed case to seck re-admission. A good average discharge rate is $10 \%$ annually of treatable cases. There will always be a proportion of cases which do not respond to treatment and they form a more or less permanent population in the settlement. When a patient is discharged he should be given a certificate to show his Chief, stating that he is not infective to others but that he must report for examination at regular intervals. Unfortunately, it sometimes happens that as a result of rousing the leprosy-consciousness of a community the villagers refuse to have back among them a patient who has been discharged from a leper settlement. This is why the giving of a certificate is necessary, and propaganda may be needed as well. Some settlements have as squatters on their margin, numbers of discharged patients who have been refused admittance back into their native villages. Every effort should be made to avoid this, as if the patients think they cannot resume life in their own villages on discharge, they will not willingly seek admission into the settlement.

Individual versus Communal Agriculture. Whether a settlement is run on the lines of individual shambas or of communal shambas (separate shambas being set aside for cultivation by infectious patients) will depend largely on the character of the tribe comprising the majority of the inmates, and also on the fertility of the soil. Every settlement has its own problems which have to be solved, and it is for this reason that interchange of ideas and mutual discussion of difficulties between those in iimmediate.control of different settlements is to be encouraged.

Makete settlement may be taker as a good example of the small-holder type of settlement in contrast to that where cultivation is on communal lines. Individual cultivation is more in 
keeping with the independent and industrious character of the local tribe, the Wanyakyusa, and every endeavour has been made to preserve the natural conditions of viliage life. Thus the inmates live in huts of their owr consiruction built of bamboo framework with or without mud filling in the walls, and of the style to which they and their families have always been accus: tomed. More attention is paid however, to sanitary principles as regards ventilation and floor-surfacing, and each hut has its own pil latrine. Around the huts are banana groves, and behind is the cultivated shamba. The Wanyakyusa are a cattle-keeping community, and in the settlement most of the inmates have domestic stocks of some description. (There are some 300 head of cattle, 50 pigs and numer(sus goals-and chickens). The site of the settlement is amongst undulating country at an average altitude of 4,000 feet. The land is fertile, well-watered, (tributaries of the Kiwira river flow througn it) and there is an abundant rainfall. The settlement comprises three villages about half-a-mile apart from each other. The average population is about 1,500 living in 600 houses, of whom about 1,000 were under treatment during 1944. Open cases are about $12.5 \%$ of all cases of leprosy in the settiemeni. The supervision and control of the settlement are carried out by Mr. Lambert, a British Empire Leprosy Association Toc $\mathrm{H}$ Worker, with an African staff.

There are two dispensaries, but as yet no hospital. The keynote of the settlement is that all who can work must work, and this has resulted in a heightened morale. Even those who are crippled and who have lost most of their fingers and toes, are given work to do, although it may be only sweeping or weeding paths. For this they are paid a small sum of money. The fact that all inmates have work to do enables them to overcome the depressing feeling of being no longer of use and of being derelicts or outcast. The new cheerfulness thus gained aids them in combating their disease and attaining a better general physical state.

On admission to the settlement a newcomer uses his own money (if he has any) until he has cultivated sufficient ground to be self-supporting. If he has no money, or insufficient money, he lodges with one of the more piosperous residents. $\mathrm{He}$ is given bamboo poles with which to buid, his house. $\mathrm{He}$ is also given work to do for part of the day, and this pays for his food. When his house is nearly completed, he is given Shgs: 2/- as a reward, The house must have a minimum size of $I, 500 \mathrm{sq}$. ft. and must have a pit latrine of a specified minimum depth. The newcomer is given a small plot of land, about one-fifth of an acre. On 
completing the cultivation of this he is given Shg. I/-. Gradually thereafter, he is given other and larger plots which he cultivates under the advice and supervision of the Agricultural Overseer. The minimum amount of land considered necessary for any one household is five acres, allowing for resting part of it in rotation. Special provision is made for widows and for those who are crippled. The widows work on communal shambas, after the preliminary breaking up of the ground has been done for them. A certain number of communal shambas have to be maintained. These provide food for newcomers and for widows and cripples. There, also, crops are grown for seed purposes. 